\title{
Antigen Absorption by the Jejunal Epithelium of Children with Cow's Milk Allergy
}

\author{
MARTINE HEYMAN, ETIENNE GRASSET, ROBERT DUCROC, AND JEHAN- \\ FRANÇOIS DESJEUX \\ INSERM, Paris [M.H., J-F.D.]; CEPHAC Recherche Clinique, Créteil [E.G.]; and Université Paris VII, \\ Jussieu, Paris [R.D.]
}

\begin{abstract}
To establish if intestinal permeability to exogenous antigens is involved in cow's milk allergy (CMA) in infants, 33 children 1 to 24 months old (18 controls and 15 with CMA) were tested for intestinal permeability to the protein marker horseradish peroxidase (HRP). Jejunal biopsies were performed either during the initial period of diagnosis, at the mean (and SE) age of 3 \pm 1 months, and/or $1 \mathrm{yr}$ later, at the age of $13 \pm 2$ months, just before and after a milk challenge. A small fragment of the biopsy was studied for histology and the remainder was mounted in an Ussing chamber for simultaneous measurement of mucosal to serosal transport of HRP in its intact and degraded forms and electrical parameters including short-circuit current and conductance. No modification in HRP absorption was noted in control children aged from 2 months to $11 \mathrm{yr}$, indicating that gut closure probably occurred earlier in life. During the initial period of CMA, transepithelial HRP fluxes were significantly higher, about 8-fold, in children with CMA (intact HRP flux = 48.5 \pm $15.2,95 \%$ confidence interval, 11.2 to 85.7 versus $5.9 \pm$ $1.2,95 \%$ confidence interval 2.9 to 8.3 , in control children) In addition, short-circuit current was increased but conductance was unchanged. After several months on a milkfree diet, HRP flux and short-circuit current returned to control values. Just after the milk challenge and independently of the clinical issue, a slight rise in HRP permeability was observed but it was not significant and remained within control values. These results suggest that increased permeability to proteins is probably not the primary cause of CMA, and that the increase in protein endocytosis noted during the initial period of CMA seems rather to be a secondary effect of an abnormal immunological response leading to mucosal inflammation and impairment of the endocytic process. (Pediatr Res 24:197-202, 1988)
\end{abstract}

\section{Abbreviations}

CMA, cow's milk allergy

HRP, horseradish peroxidase

JHRP, IHRP flux

Isc, short-circuit current

$G$, ionic conductance

PD, potential difference

The pathogenesis of CMA is still unclear, inasmuch as it is not known if CMA infants have an increased intestinal permeability

Received December 28, 1987; accepted April 5, 1988.

Correspondence and reprint requests Martine Heyman, INSERM U.290, Hôpital Saint-Lazare, 107 bis, Rue du Faubourg Saint-Denis, 75010 Paris, France. to dietary protein antigens that abnormally stimulate the immune system or if normal intestinal permeability to proteins leads to a pathological immune response in some given individuals. Gastrointestinal permeability has been studied in atopic patients using different probe molecules such as polyethylene glycol (1-3), ${ }^{51} \mathrm{Cr}$ EDTA (4), rhamnose or lactulose (5), or ovalbumin (6). Increased absorption of PEG 4000 was reported in patients with eczema and food allergy (3), but no changes in permeability to PEG 400 or 1000 were recorded in allergic children on an elimination diet compared to healthy children (1). Increased intestinal permeability was only noted after milk challenge (2). In children with egg sensitivity, no significantly increased absorption of ovalbumin was demonstrated compared to control values, but reduced permeability was observed with sodium cromoglycate.

In recent years, we have used a model of protein transport whose tracer macromolecule is the glycoprotein HRP (mol. wt. $40,000)$. We showed that this protein was transported across the intestinal epithelium by endocytosis along two functional pathways: a minor route allowing transfer of the intact protein and a major route involving lysosomal degradation during transport $(7,8)$. In infants, serial intestinal biopsies have been recommended before and after open challenges to further confirm the diagnosis of CMA $(9-11)$. Our purpose herein was to evaluate HRP uptake and degradation by the intestinal epithelium of infants with CMA, using serial jejunal biopsies taken at different stages of the disease.

\section{PATIENTS}

A total of 33 children was examined, 15 with CMA and 18 controls. Peroral biopsies were taken from all children for diagnosis after informed consent had been obtained from their guardians according to the recommendations of the department of pediatrics. Some of the children with CMA underwent two or three biopsies at different stages of the disease.

Control children. Fifteen of the 18 children in this group were 2 to 30 months old (mean age $13.3 \pm 2.2$ ) and the three others were 5 to $11 \mathrm{yr}$ old. All were free of any sign of CMA. Sixteen children were biopsied to investigate the etiology of growth failure. One child had known celiac disease and the biopsy was performed on a gluten-free diet to confirm that mucosal histology was normal. Another child had undergone jejunostomy and the biopsy was taken $10 \mathrm{~cm}$ from the skin. Except in the latter case, biopsies were performed near the ligament of Treitz with a Carey capsule (12) under fluoroscopic control. Criteria for inclusion in the control group were the absence of any intestinal dysfunction at biopsy and a normal histological appearance of the mucosa.

CMA children. Clinical data concerning these 15 children are given in Table 1 . The diagnosis was mainly based on clinical observations during short-term challenge. While on a diet containing cow's milk, all children experienced diarrhea and/or 
vomiting and weight loss but these disorders were resolved by a milk-free diet. No villus atrophy was noted but an important inflammatory infiltration was noted. After a few days on an exclusion diet in the pediatric unit, at least one milk challenge proved positive. This initial challenge was omitted for two children (LA and OD) who presented with adverse systemic reactions at the time of diagnosis. The initial biopsy was performed at 5.2 \pm 2.0 days, soon after milk administration. When necessary, the possibility of dissacharidase deficiency was ruled out by stool examination for $\mathrm{pH}$ and reducing sugars, a hydrogen breath test, or direct biopsy analysis for dissacharidase.

For the challenge, the initial amount of milk was usually 10 $\mathrm{ml}$ with a 4-h interval before a second larger amount was given. In cases of previous adverse systemic reactions, the first amount was reduced to $1 \mathrm{ml}$ and was followed by a 4-h observation period. After the challenge, cow's milk ingestion was either stopped or rapidly increased in order to reach normal milk intake $24 \mathrm{~h}$ later. Children on a diet free of cow's milk protein were maintained on a protein hydrolysate diet for several months.

The children with CMA were divided into three groups. Group I: After the initial milk challenge. This group consisted of seven children aged from 3 wk to 4.5 months (mean age $3.0 \pm 0.9$ months), diagnosed as previously described, who had undergone an intestinal biopsy at the very beginning of the disease, i.e. within only 5 days of a positive milk challenge. At the time of biopsy, they were on a protein hydrolysate formula (Alfaré, Nestlê, Pregestimil, or Nutramigen, Mead-Johnson).

Group II: Before late milk challenge. This group was composed of six children (mean age: $12.7 \pm 2.3$ months) who had been maintained on a cow's milk-free diet for at least 4 months and had come to the hospital for a new milk challenge. They were biopsied just before the challenge for examination of their mucosal histology and intestinal HRP permeability during the exclusion diet.

Group III: After late milk challenge. This group was comprised of nine children who had been on a cow's milk-free diet for several months and had also come for a new milk challenge (mean age $12.8 \pm 1.8$ months). A biopsy was performed 24-48 $\mathrm{h}$ after the challenge. Children with positive $(n=5)$ and negative $(n=4)$ challenges are designated subgroups IIIa and IIIb, respectively. Of the 15 children with CMA studied, one child (MS) underwent three serial biopsies (I, II, and III), four children (MS, MAB, DB, and MQ) underwent two biopsies (II and III), and another (MJ) underwent two biopsies (I and III). The remaining children were biopsied once only or underwent several biopsies, but the fragments obtained were not large enough to allow measurement of HRP permeability in an Ussing chamber.

Herein, most of the children clinically intolerant to cow's milk

Table 1. Clinical results of children with CMA at different stages of disease

\begin{tabular}{|c|c|c|c|c|c|c|c|c|c|}
\hline Patients & $\begin{array}{l}\text { Age* } \\
(\mathrm{mo})\end{array}$ & $\begin{array}{c}\text { Diar- } \\
\text { rhea }\end{array}$ & $\begin{array}{c}\text { Fecal } \\
\text { blood } \\
\text { loss }\end{array}$ & $\begin{array}{l}\text { Wt } \\
\text { loss }\end{array}$ & $\begin{array}{l}\text { Vomit- } \\
\text { ing }\end{array}$ & $\begin{array}{c}\text { Paroxysmal, } \\
\text { systemic } \\
\text { adverse reactions }\end{array}$ & $\begin{array}{c}\text { Clinical response } \\
\text { to cow's milk } \\
\text { challenge }\end{array}$ & Histology & IgE to cow's milk \\
\hline \multicolumn{10}{|l|}{ Group I } \\
\hline LY & 1 & + & & + & + & & + & ${ }^{\uparrow \dagger}$ Plasmocytes & - \\
\hline NM & 1 & + & & + & + & & + & ${ }^{\uparrow}$ Eosinophils & \\
\hline MJ & 4 & + & & + & + & + & + & Normal & - \\
\hline LO & $4 \frac{1}{2}$ & + & & + & + & & + & $\begin{array}{l}\uparrow \text { Plasmocytes } \\
\text { Eosinophils }\end{array}$ & \\
\hline LA & 7 & + & + & & + & + & & $\begin{array}{l}\text { Partial villus atrophy } \\
{ }^{\uparrow} \text { Plasmocytes }\end{array}$ & $\begin{array}{l}+ \\
(\alpha \text {-lactalbumin and } \\
\beta \text {-lactoglobulin })\end{array}$ \\
\hline OD & 1 & + & + & & & + & & ${ }^{\uparrow}$ Mast cells & \\
\hline MS & 2 & + & & + & + & & + & $\begin{array}{l}\uparrow \text { Lymphocytes } \\
\uparrow \text { Plasmocytes }\end{array}$ & - \\
\hline \multicolumn{10}{|l|}{ Group II } \\
\hline MA & 17 & + & + & + & & & + & Normal & \\
\hline MS & 6 & + & + & + & + & & ++ & Normal & - \\
\hline MS $\ddagger$ & 14 & + & + & & + & & +++ & Normal & \\
\hline MAB & 14 & + & & + & + & + & + & Normal & - \\
\hline MQ & 24 & + & & + & & & & Normal & \\
\hline DB & 9 & + & & + & + & & + & Partial atrophy & - \\
\hline \multicolumn{10}{|l|}{ Group IIIa } \\
\hline MS & 6 & + & + & & + & & ++ & Normal & - \\
\hline $\mathrm{DE}$ & 9 & + & + & & + & & + & Slight villus atrophy & $\begin{array}{l}+ \\
\text { (LT } \\
\quad \text { globulin) }\end{array}$ \\
\hline MJ & 16 & + & & & & & + & Normal & \\
\hline MS & 14 & + & + & & + & & +++ & Normal & - \\
\hline DB & 9 & + & & + & + & & + & Partial atrophy & - \\
\hline \multicolumn{10}{|l|}{ Group IIIb } \\
\hline MQ & 24 & & & & & & - & Inflammation & \\
\hline MAB & 14 & & & & & & - & Normal & - \\
\hline AM & 9 & & & & & & - & Normal & \\
\hline ME & 14 & & & & & & - & Normal & - \\
\hline
\end{tabular}

* At biopsy.

$\dagger$ Increased mucosal inflammation.

¥ Same child biopsied twice before each of two positive challenges. Clinical results of group II infants are those obtained after the milk challenge, except histological results that are those of the biopsy taken before the milk challenge.

$\S$ Lymphoblastic stimulation test. 
had a negative milk protein radioallergosorbent test, suggesting that IgE-mediated hypersensitivity was not constant. This was also reported in previous studies of CMA patients whose serum $\mathrm{IgE}$ were normal (13-15)

Histological appearance of the mucosa of CMA patients was not strikingly altered. Group I children consistently presented no villus atrophy but an inflammatory infiltration of the submucosa, and in most cases the mucosa normalized after a milk free diet of several months.

\section{METHODS}

In vitro HRP transport studies. Each biopsy was laid flat on a Millipore filter (HAMK $0.45 \mu \mathrm{m}$ ). Filter and biopsy were mounted in a small Ussing chamber and bathed on both sides with $1.5 \mathrm{ml}$ of Ringer solution ( $\mathrm{pH} 7.4$ ) containing in $\mathrm{mM}: 140$ $\mathrm{Na}, 5.2 \mathrm{~K}, 1.2 \mathrm{Ca}, 1.2 \mathrm{Mg}, 120 \mathrm{Cl}, 25 \mathrm{HCO}_{3}, 2.4 \mathrm{HPO}_{4}$, and 0.4 $\mathrm{H}_{2} \mathrm{PO}_{4}$. The exposed surface area was $10 \mathrm{~mm}^{2}$. Silicone paste (Rhodorsil, Rhône-Poulenc, France) was used to minimize edge damage. The Isc that is an index of active electrolyte transport by the epithelium, and the tissue $G$ that is an index of electrolyte permeability through the paracellular pathway were measured as follows: the solutions bathing the mucosal and serosal sides of the tissue were connected to calomel electrodes via $3 \mathrm{M} \mathrm{KCl}$ agar bridges for measurement of the transepithelial PD, and to Ag$\mathrm{AgCl}$ electrodes for the passage of current through the system. The biopsy was short-circuited by an automatic voltage clamp that compensated for the resistance of the fluid and of the filter itself. Current pulses enabled us to measure tissue conductance at regular intervals.

HRP (Sigma type VI, Sigma Chemical Co., St. Louis, MO) was used as described earlier $(7,8)$ to quantitate permeability to the protein in its intact and degraded forms. Briefly, HRP at a final concentration of $10 \mu \mathrm{M}(0.4 \mathrm{mg} / \mathrm{ml})$ was added to the mucosal compartment and $\left.{ }^{3} \mathrm{H}\right] \mathrm{HRP}$, prepared and stored as previously reported (7), was also added as a tracer $(1.33 \mu \mathrm{Ci} / \mathrm{ml})$. For $110 \mathrm{~min}, 800-\mu \mathrm{l}$ samples were taken from the serosal compartment at 10 - and 20-min intervals and replaced by fresh Ringer buffer. Mucosal to serosal fluxes of intact HRP (J intactHRP) were determined by enzymatic assay on $200-\mu$ l aliquots of the serosal sample according to the modified Worthington method (16). Tritium fluxes (corresponding to intact plus degraded HRP) were assessed by tritium counting on the remaining $500-\mu 1$ aliquots, using liquid scintillation photometry. Degraded HRP fluxes (J degraded HRP) were calculated as tritium fluxes minus intact fluxes.

In some experiments, the metabolic inhibitors 2-deoxyglucose $50 \mathrm{mM}+$ sodium azide $1 \mathrm{mM}$ were added on both sides of the tissue 30 min before the HRP flux measurements, or after 100 min of flux measurements in one child with CMA.

Statistical analysis. Statistical analysis was performed by using the SPSS/PC+ program (SPSS Inc, Chicago IL). Means of the several groups are given with their SE and compared by one-way analysis of variance and multiple-comparison techniques (17). When the assumption of equality of variance was questionable, nonparametric methods, such as the Kruskal-Wallis test, were also used (17). As the statistical analysis was focused on the comparison and estimation of the magnitude of the means, confidence intervals will also be reported (18).

\section{RESULTS}

Jejunal permeability to HRP in control children. As shown in Figure 1 and Table 2, HRP was mainly transported across the epithelium of control children in degraded form (88\%) but a significant percentage $(12 \%)$ was transported in intact form. Transepithelial fluxes increased with time and reached a steady state after 60-80 min. Consequently, the subsequent flux values were the means of the three last fluxes, measured between 60 and $100 \mathrm{~min}$. The $95 \%$ confidence intervals for intact and degraded JHRP were 2.9 to 8.3 and 24.5 to $54.3 \mathrm{pmol} \cdot \mathrm{h}^{-1} \cdot \mathrm{cm}^{-2}$, respectively. There was no change in intact or degraded protein permeability as a function of age in children of 2 months to 11 yr (Fig. 2) suggesting that intestinal closure to macromolecules is effective before the age of 2 months. The addition of metabolic inhibitors $30 \mathrm{~min}$ before the flux measurements led to a complete inhibition of both intact and degraded JHRP (results not shown, estimated in three control children).

Jejunal permeability to HRP in children with CMA. As reported in Figures $3 A$ and $B$, steady state JHRP were about 8fold higher in children in the active stage of CMA (group I). By one-way analysis of variance, the difference was significant for both intact $(p<0.001)$ and degraded $(p<0.01)$ HRP fluxes. (A correlation analysis taking into account all measured HRP fluxes, i.e. from both control and CMA children, confirmed that these two parameters are correlated, with a one-tailed significance value of $p<0.05$.)

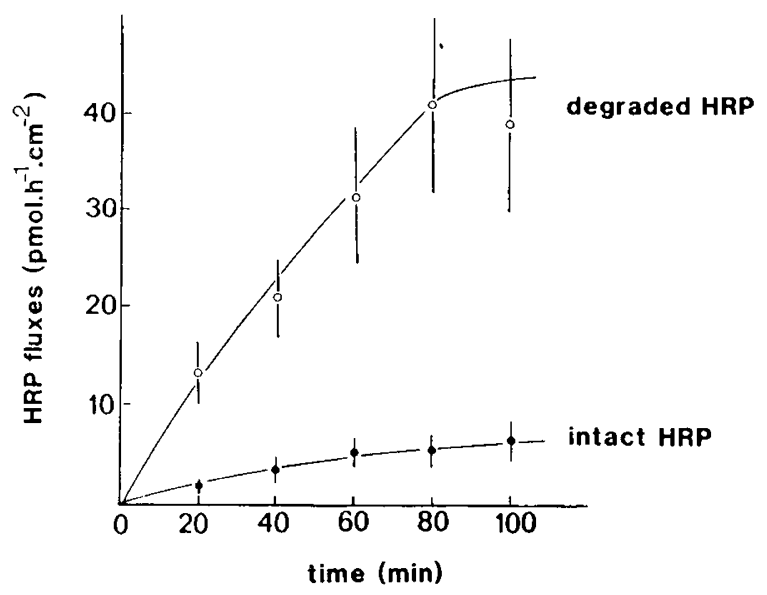

Fig. 1. HRP absorption in control children. Mucosal to serosal fluxes of intact $(\bullet)$ and degraded HRP $(O)$ across the jejunal epithelium of control children as a function of time $(n=18)$. Values are plotted as mean $\pm S E$.

Table 2. Transepithelial intact or degraded HRP fluxes from mucosa to serosa across jejunal epithelium of control children and children with $C M A^{*}$

\begin{tabular}{|c|c|c|c|c|c|c|}
\hline & \multirow[b]{2}{*}{$n \dagger$} & \multirow{2}{*}{$\begin{array}{l}\text { Age } \\
(\mathrm{mo})\end{array}$} & \multirow{2}{*}{$\begin{array}{l}\text { Intact } \\
\text { JHRP }\end{array}$} & \multirow{2}{*}{$\begin{array}{l}\text { Degraded } \\
\text { JHRP }\end{array}$} & \multicolumn{2}{|c|}{$\%$ HRP transported } \\
\hline & & & & & Intact & Degraded \\
\hline Controls & 18 & $13.3 \pm 2.2$ & $5.92 \pm 1.24$ & $39.41 \pm 6.96$ & 12.5 & 87.5 \\
\hline Group I & 7 & $2.9 \pm 0.9$ & $48.46 \ddagger \pm 15.22$ & $471.50 \div \pm 236.25$ & 9.3 & 90.7 \\
\hline Group II & 6 & $12.7 \pm 2.3$ & $8.18 \pm 2.20$ & $51.41 \pm 16.20$ & 13.7 & 86.3 \\
\hline Group IIIa & 5 & $10.8 \pm 1.8$ & $13.62 \pm 5.18$ & $73.44 \pm 40.14$ & 15.6 & 84.4 \\
\hline Group IIIb & 4 & $15.2 \pm 3.1$ & $13.20 \pm 2.75$ & $67.58 \pm 48.07$ & 8.9 & 91.1 \\
\hline
\end{tabular}

\footnotetext{
* Values recorded as mean and SE.

$\dagger$ Number of children in each group.

$¥$ Significantly different from controls (see text for details).
} 


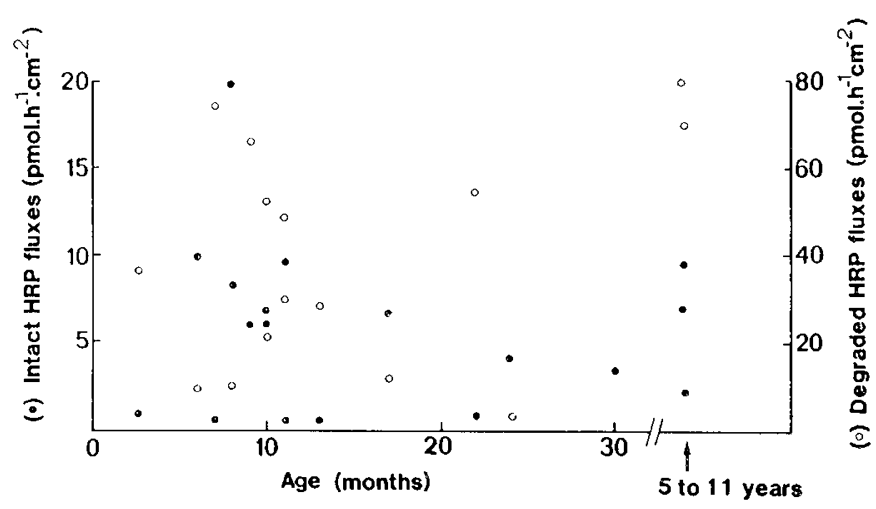

Fig. 2. Ontogenesis of HRP absorption. Mucosal to serosal fluxes of intact $(\bullet)$ and degraded $(O)$ HRP across the jejunal epithelium of control children as a function of age. Each point represents one child.

For intact JHRP, detailed examination of group I values (95\% confidence limits 11.19 to $85.72 \mathrm{pmol} \cdot \mathrm{h}^{-1} \cdot \mathrm{cm}^{-2}$ ) showed that this group also exhibited an increased dispersion, with increased variance. The nonparametric Kruskal-Wallis test, which does not depend on normality and equality of variance, also confirmed the significance of this difference $(p<0.001)$. To sum up, intact JHRP of group I patients are higher and also more variable than those of other groups, and particularly than that of controls.

For degraded JHRP, the scatter observed in group I was even greater $\left(95 \%\right.$ confidence limits -136 to $\left.+1079 \mathrm{pmol} \cdot \mathrm{h}^{-1} \cdot \mathrm{cm}^{-2}\right)$ and prevented detecting a difference by the Kruskal-Wallis test.

The 8-fold rise in HRP fluxes was probably due to a transcellular increase in HRP endocytosis, inasmuch as in one biopsy from a child in group $I$, the addition of metabolic inhibitors on both sides of the tissue led to a net decrease in intact HRP fluxes (Fig. 4). After several months on a milk-free diet, this increased permeability returned to the near-control values observed in the children in group II. Immediately after the milk challenge, HRP permeability rose slightly but not significantly. This result was obtained for children in both the positive and negative milk challenge groups (IIIa and IIIb, respectively). In the four patients from whom specimens were obtained both before and after the milk challenge, no significant modifications were obtained in HRP permeability, irrespective of the outcome. These four children when on a cow's milk free diet (group II) had HRP fluxes under intact and degraded form of $8.58 \pm 3.01$ and $48.61 \pm$ $22.89 \mathrm{pmol} \cdot \mathrm{h}^{-1} \cdot \mathrm{cm}^{-2}$ and the values of these fluxes after the milk challenge were $10.38 \pm 2.46$ and $36.09 \pm 21.07 \mathrm{pmol} \cdot \mathrm{h}^{-1}$. $\mathrm{cm}^{-2}$, respectively. The simultaneous examination of the histological appearance of the biopsy and HRP transport indicated that no strict relationship was observed between these two parameters.

Electrical parameters. The electrical parameters (Table 3) obtained in control biopsies were similar to those obtained previously in children recovering from malnutrition (8), and in healthy children previously studied (19). The $95 \%$ confidence interval for Isc was 21.5 to $39.05 \mu \mathrm{A} \cdot \mathrm{cm}^{-2}$. For group I children, the average Isc value was higher $(62.7 ; 95 \%$ confidence interval 11.2 to $114.1 \mu \mathrm{A} . \mathrm{cm}^{-2}$ ), but due to the high variability the difference just failed to reach significance (one-way analysis of variance: $p=0.066$, Kruskal-Wallis test: $p=0.16$ ). This high Isc average value might reflect stimulation of electrogenic secretion probably involved in the development of diarrhea. The variability of the magnitude of Isc stimulation (i.e. the increased dispersion observed for group I patients) might indicate that this is not a constant feature of the disease. Group II, IIIa, and IIIb average Isc values did not differ from controls. The conductance remained constant at all stages of the disease and was not statistically different from the control values.

\section{DISCUSSION}

In the present study we measured the transport of proteins across isolated jejunal mucosa in control children and children
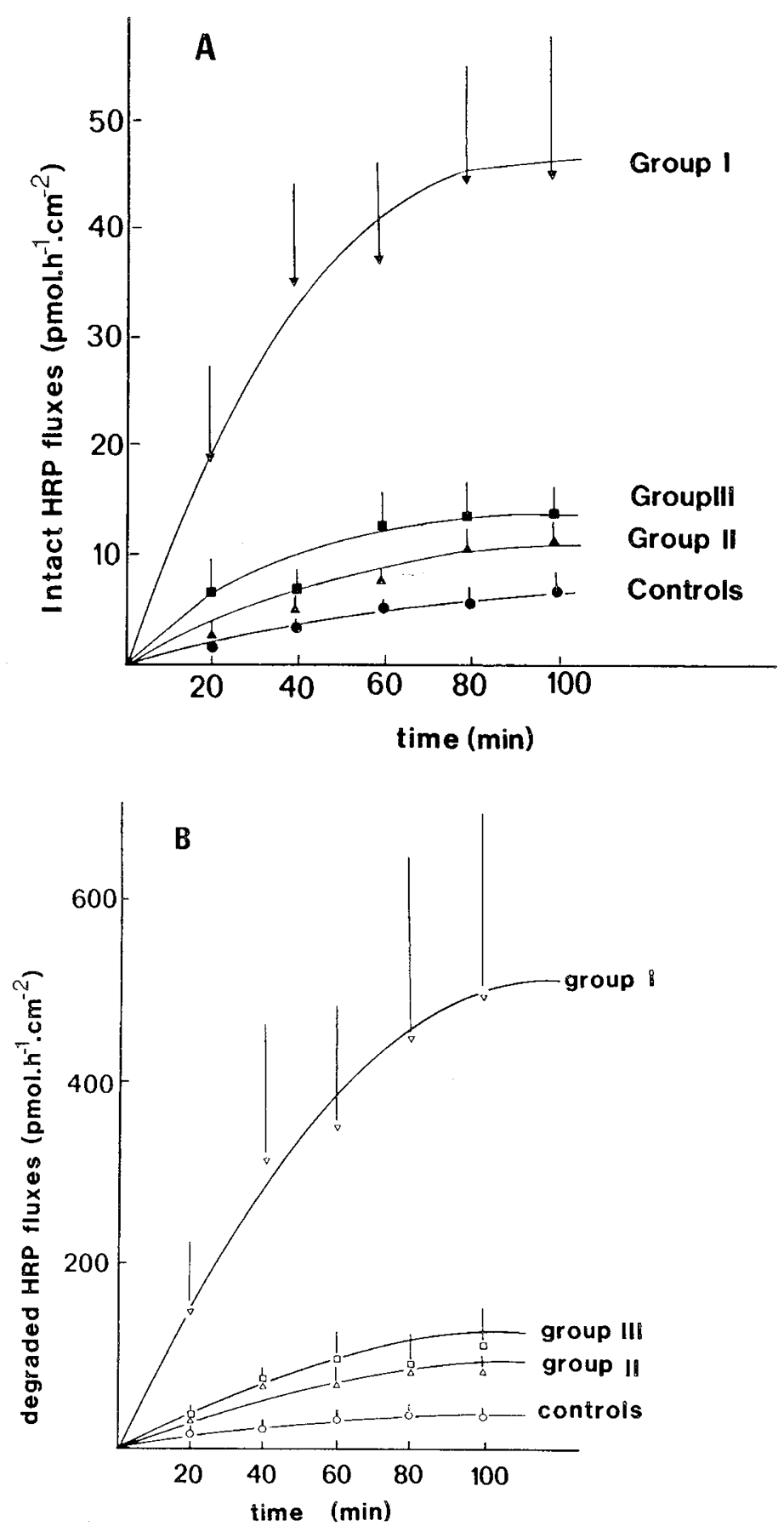

Fig. 3. HRP absorption in children with CMA plotted as mean $\pm \mathrm{SE}$. Mucosal to serosal intact $(A)$ and degraded $(B)$ HRP fluxes as a function of time across the jejunal epithelium of control children $(\bullet)$ and children with CMA : $\boldsymbol{\nabla}$ (group I), $\boldsymbol{\Delta}$ (group II), $\mathbf{\square}$ (group IIIa + b). Intact or degraded HRP fluxes calculated at steady state (mean from 60 to 100 $\mathrm{min}$ ) are increased in group I compared to other groups. Number of children studied: Controls $n=18$, group I $n=7$, group II $n=6$, group III $n=9$.

with CMA. Control children absorbed HRP by the two functional pathways previously described $(7,8)$ to a similar extent in the age range from 2 months to $11 \mathrm{yr}$. A large increase in HRP endocytosis, associated with an increase in short-circuit current, was found during the initial period of CMA when infants less than 3 months old underwent inadvertent or deliberate exposure to cow's milk antigens. These alterations were not associated with any significant change in electrical tissue conductance.

This result raises the question of whether the increased HRP absorption observed early in the disease is specific to children 


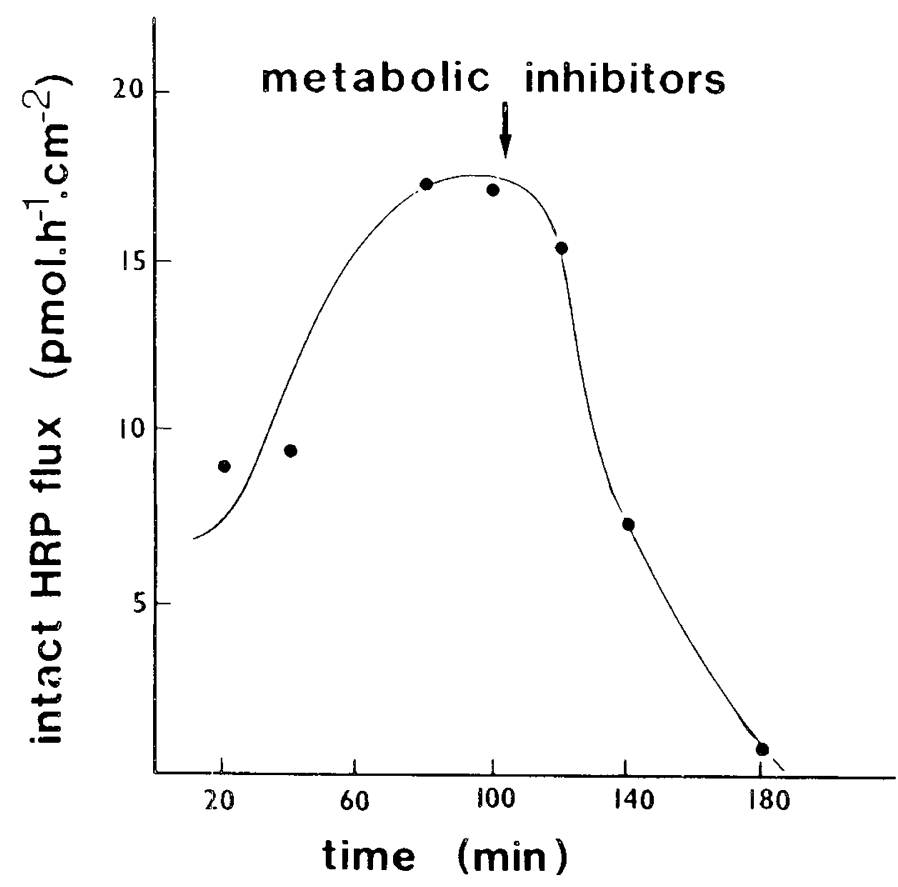

Fig. 4. Inhibition of HRP absorption in one child with CMA. Mucosal to serosal intact HRP fluxes in a 1-month-old child with CMA in group I as a function of time. Note that the high HRP permeability was completely abolished by the addition of metabolic inhibitors $(50 \mathrm{mM} 2$ deoxyglucose $+1 \mathrm{mM}$ sodium azide) on both sides of the tissue.

Table 3. Electrical parameters of jejunal biopsies from control children and children with CMA*

\begin{tabular}{|c|c|c|c|c|}
\hline & $n \dagger$ & $\begin{array}{c}\text { Potential } \\
\text { difference } \\
(\mathrm{mV})\end{array}$ & $\begin{array}{c}\mathrm{G} \\
\left(\mathrm{mS} / \mathrm{cm}^{2}\right)\end{array}$ & $\begin{array}{c}\text { Isc } \\
\left(\mu \mathrm{A} / \mathrm{cm}^{2}\right)\end{array}$ \\
\hline Controls & 12 & $-0.94 \pm 0.18$ & $38.80 \pm 6.93$ & $30.29 \pm 3.98$ \\
\hline CMA-group I & 6 & $-1.32 \pm 0.47$ & $48.20 \pm 3.88$ & $62.66 \neq \pm 20.02$ \\
\hline CMA-group II & 6 & $-0.89 \pm 0.08$ & $39.56 \pm 7.32$ & $32.54 \pm 3.35$ \\
\hline CMA-group IIIa & 5 & $-0.79 \pm 0.26$ & $38.03 \pm 10.46$ & $27.37 \pm 9.88$ \\
\hline CMA—group IIIb & 4 & $-0.88 \pm 0.26$ & $31.5 \pm 4.15$ & $33.90 \pm 6.46$ \\
\hline
\end{tabular}

* Values recorded as mean and SE.

$\dagger$ Number of children in each group.

$\ddagger$ Different from other values at $p=0.07$ (see text for details).

with CMA or whether this increase is part of the postnatal development of intestinal permeability to proteins. Indirect evidence has led various authors to state that infants naturally absorb more macromolecules acting as antigens than older children, because infants were found to have more antibodies to food antigens than older children (20). However, other authors pointed out that the intestinal barrier to antigens was efficient at birth. Thus, Robertson et al. (21), who measured the concentration of $\beta$-lactoglobulin after feeding preterm and term neonates with a cow's milk-based formula, showed that the ability of the gastrointestinal tract to exclude antigenically intact food proteins increases with gestational age, but that in humans, gut closure normally occurs before birth. Similarly, Jakobsson et al. (22) reported that the human $\alpha$-lactalbumin concentration after human milk feeding was higher in the serum of preterm infants than in term infants aged 5 to 30 days. In our study, we did not find an increase in HRP transport in the mucosa of the youngest infant (2 months) of the control group. We have preliminary evidence that HRP is an appropriate marker of cow's milk proteins such a $\beta$-lactoglobulin or $\alpha$-lactalbumin. Indeed, in rabbit intestine, these two proteins are transported to a similar extent as HRP in our study (23). Milk protein transport should be measured across human intestinal biopsies before conclusions can be drawn, however, we think that HRP transport might well reflect $\beta$-lactoglobulin or $\alpha$-lactalbumin transport.

Our results suggest that in humans, intestinal closure to nonimmunoglobulin proteins occurs before the age of 2 months and indicate that the increased permeability observed at the early stage of the disease is not related to a developmental process. One could also argue that the increased HRP permeability is related to a delay in the physiological phenomenon of closure. However, this possibility is unlikely in view of the simultaneous increase in Isc.

The increased permeability to HRP observed herein during the acute phase of CMA is probably not due to disruption of the mucosa but rather to an increase in a transcellular absorption. This conclusion is based on the following data: 1) The electrical tissue conductance which is a good index of the electrolyte paracellular pathway in the small intestine (24) was not increased at any stages of the disease. 2) The rise in intact HRP absorption was associated with a parallel rise in degraded-HRP absorption which is obligatory transcellular. 3) In one child with CMA, HRP transport was inhibited by the addition of metabolic inhibitors to the bathing solutions. 4) The histological appearance of the jejunal mucosa of the group I infants only displayed abnormalities at the lamina propria level, with increased cellularity indicating an inflammatory process. Additionally, no detectable alterations were observed at least by the light microscopic examination of the epithelial layer.

The increase in HRP transport is a transient phenomenon associated with an increase in Isc. The increase in Isc in the active phase of the disease is reminiscent of the increase in Isc due to active chloride secretion after luminal ovalbumin challenge in rats already sensitized to ovalbumin (25). There is considerable evidence that the antigen stimulation of plasmocytes in the lamina propria of the gut mucosa produces an increase in Isc due to the liberation of many mediators that directly or undirectly stimulate water and electrolyte secretion (26). In our experiments, the increase in Isc could be due to the persistence of chloride secretion induced by cow's milk proteins in vivo. During the initial phase of CMA, there is always an inflammatory response in the lamina propria $(27,28)$. It is conceivable that locally released lymphokines stimulated the endocytic process. We therefore suggest that the increased permeability to antigenic molecules in the acute phase of CMA might be due to stimulation of the fluid-phase endocytic process, possibly by the prolonged effect of the lymphokines or mediators locally released from sensitized cells. In that case, the epithelial dysfunction in CMA would be the consequence of submucosal dysfunction. The lack of increased HRP uptake after positive cow's milk challenge in older children could be due to the short duration of milk challenge (less than $48 \mathrm{~h}$ ) compared to the longer duration at the initial stage of investigation (several days or weeks).

Taken together, our results indicate that in infancy there is a basal permeability to dietary proteins in their intact and degraded forms which seem constant from 2 months of age. Thus, in our series, infants with CMA exhibited increased absorption of both intact and degraded proteins probably on account of the inflammatory process associated with the disease. This increased absorption is not likely to be constitutive, inasmuch as normal permeability was restored by a diet free of milk proteins.

Acknowledgments. The authors thank Pr. J. P. Cézard for allowing us to study two infants and Bernard Piot (TRIAD, F95250 Beauchamp) for performing the statistical analysis. They are also grateful to $\mathrm{F}$. Berthet for secretarial assistance and $\mathrm{M}$. Dreyfus for revising the manuscript.

\section{REFERENCES}

1. Fälth-Magnusson K, Kjellman NIM, Magnusson KE, Sundqvist T 1984 Intestinal permeability in healthy and allergic children before and after sodium cromoglycate treatment assessed with different-sized polyethyleneglycols 
(PEG 400 and PEG 1000). Clin Allergy 14:277-286

2. Fälth-Magnusson K, Kjellman NIM, Odelram H, Sundqvist T, Magnusson KE 1985 Gastrointestinal permeability in children with cow's milk allergy: effect of milk challenge and sodium cromoglycate as assessed with polyethyleneglycols (PEG 400 and PEG 1000). Clin Allergy 16:543-551

3. Jackson PG, Lessof MH, Baker RWR, Ferrett J, McDonald DM 1981 Intestinal permeability in patients with eczema and food allergy. Lancet 1:1285-1286

4. Forget P, Sodoyez-Goffaux F, Zappitelli A 1985 Permeability of the small intestine to $\left[{ }^{51} \mathrm{Cr}\right]$ EDTA in children with acute gastroenteritis or eczema. J Pediatr Gastroenterol Nutr 4:393-396

5. Dumont GCL, Beach RC, Menzies IS 1984 Gastrointestinai permeability in food-allergic eczematous children. Clin Allergy 14:55-59

6. Dannaeus A, Johannson SGO 1979 A follow-up study of infants with adverse reactions to cow's milk. 1. Serum IgE, skin test reactions and RAST in relation to clinical course. Acta Paediatr Scand 68:377-382

7. Heyman M, Ducroc R, Desjeux JF, Morgat JL 1982 Horseradish peroxidase transport across adult rabbit jejunum in vitro. Am J Physiol 242:G558G564

8. Heyman M, Boudraa G, Sarrut S, Giraud M, Evans L, Touhami M, Desjeux JF 1984 Macromolecular transport in jejunal mucosa of children with severe malnutrition: a quantitative study. J Pediatr Gastroenterol Nutr 5:463-466

9. Fontaine JL, Navarro J 1975 Small intestinal biopsy in cow's milk protein allergy in infancy. Arch Dis Child 50:357-362

10. Walker-Smith J, Harrison M, Kilby A, Phillips A, Norman F 1978 Cow's milksensitive enteropathy. Arch Dis Child 53:375-380

11. Vitoria JC, Camarero C, Solaguren R, Aranjuelo M, Oliveros R, Navajas A, Rodriguez-Soriano J 1979 Cow's milk protein-sensitive enteropathy. Clinical and histological results of the cow's milk provocation test. Helv Paediatr Acta 34:309-318

12. Carey JB 1964 A simplified gastrointestinal biopsy capsule. Gastroenterology 46:550-557

13. Hill DJ, Davidson GP, Cameron DJS, Barnes GL 1979 The spectrum of cow's milk allergy in childhood. Acta Paediatr Scand 68:847-852

14. Dannaeus A, Inganäs M, Johansson SGO, Foucard T 1979 Intestinal uptake of ovalbumin in malabsorption and food allergy in relation to serum $\mathrm{IgG}$ antibody and orally administered sodium cromoglycate. Clin Allergy 9:263270

15. Ford RPK, Hill DJ, Hosking CS 1983 Cow's milk hypersensitivity: immediate and delayed onset clinical patterns. Arch Dis Child 58:856-862

16. Maehly AC, Chance B 1954 The assay of catalases and peroxidases. In: Glick $\mathrm{D}$ (ed) Methods of Biochemical Analysis, Vol 1. Wiley Interscience, New York, pp 357-398

17. Godfrey K 1985 Comparing the means of several groups. N Engl J Med 313:1450-1456

18. Pocock SJ, Hughes MD, Lee RJ 1987 Statistical problems in the reporting of clinical trials. N Engl J Med 317:426-432

19. Grasset E, Heyman M, Dumontier AM, Lestradet H, Desjeux JF 1979 Possible sodium and D-glucose cotransport in isolated jejunal epithelium of children. Pediatr Res 13:1240-1246

20. Walker WA 1975 Antigen absorption from the small intestine and gastrointestinal disease. Pediatr Clin North Am 22:731-746

21. Robertson DM, Paganelli R, Dinwiddie R, Levinsky RJ 1982 Milk antigen absorption in the preterm and term neonate. Arch Dis Child 57:369-372

22. Jakobsson I, Lindberg T, Lothe L, Axelsson I, Benediktsson B 1986 Human $\alpha$-lactalbumin as a marker of macromolecular absorption. Gut 27:10291034

23. Marcon-Genty D, Kheroua O, Tomé D, Dumontier AM, Desjeux JF 1987 Intestinal transepithelial passage of bovine milk proteins antigens in vitro. Pediatr Res 22:223(abstr)

24. Desjeux JF, Tai YH, Curran PF 1974 Characteristics of sodium flux from serosa to mucosa in rabbit ileum. J Gen Physiol 64:274-292

25. Perdue MH, Gall DG 1986 Intestinal anaphylaxis in the rat: jejunal response to in vitro antigen exposure. Am $\mathbf{J}$ Physiol 250:G427-G43

26. Castro GA, Harari Y, Russell D 1987 Mediators of anaphylaxis-induced ion transport changes in small intestine. Am J Physiol 253:G540-G548

27. Savilahti E, Verkasalo M 1984 Intestinal cow's milk allergy: Pathogenesis and clinical presentation. Clin Rev Allergy 2:7-23

28. Kosnai I, Kuitunen P, Savilahti E, Sipponen P 1984 Mast cells and eosinophils in the jejunal mucosa of patients with intestinal cow's milk allergy and celiac disease of childhood. J Pediatr Gastroenterol Nutr 3:368-372 